\title{
Re-imagining Business Schools of the Future as Places of Theorizing
}

Hugo Gaggiotti, Peter Simpson and Svetlana Cicmil

\section{Introduction}

In a dialogue with his master William, Adso, intrigued by the nature and purpose of learning, asks: "Then why do you want to know?" The master responded: "Because learning does not consist only of knowing what we must or we can do, but also of knowing what we could do and perhaps should not do." (Eco, 2014 [1980], 107). Indeed, 'knowing what we must or we can do' has been part of the Business School tradition of teaching 'best practice' through which students learn to apply the lessons derived from exemplars of successful business models, practices and theories. This approach has been further reinforced by the contemporary obsession with "employability", "production of able and ready graduates" and Business Schools' adoption of similar performance indicators. Most, if not all, institutions would claim that by the end of a programme of study their students will know what they should do. However, most institutions would be less confident in claiming that their alumni, in the pressure cooker of challenging business situations, are able to 
respond to the second part of the master's response and resist the temptation to do what 'we could do and perhaps should not do' (Eco, 2014 [1980], 107).

In this chapter, we argue that one of the reasons for this is the emphasis on the application of theories to the exclusion of theorizing. Czarniawska argues that works of theory are rare in organization and management studies, surrounded by a confusion around what theorising might mean, including "a tendency to call literature reviews "theoretical papers" $(2013,113)$. Macfarlane (1988) suggested that this confusion could be the result of the "tribal" academic and intellectual roots of management scholars, traditionally very diverse and usually not from organizational or management studies. The implication is that theory is not developed by theorizing in Business Schools but is something that is sourced from elsewhere and then "used", consisting of models or concepts imported from other disciplines that students, academics, and researchers are encouraged to "apply". We argue that Business Schools should engage in and contribute to the intellectual practice of academic theorizing and not merely to be places of reproduction, application and enumeration of theories.

We wish to address the pertinent theme of reimagining the university of the next century (e.g. Boni and Walker, 2013) by focusing on Business Schools as a particular case of academic institutions that could be at the centre of scientific reflection on the socioeconomic challenges, like unemployment and corruption, that our societies will face in the future. We consider possible ways of reimagining the future of these organizations as if the practice of theorizing mattered in teaching and learning.

We use the example of business ethics to illustrate the risks emanating from further marginalization of theorizing. Business ethics exemplifies how an area of prolific philosophical production of theories and models has not led to any significant impact on the way business is practiced. We suggest that such failure is, in part, rooted in 
the way the subject of ethics is understood in Business Schools (namely, the ethical is separated from the theoretical). Another reason, we argue, is related to the common teaching method which invites students to rhetorically demonstrate their capacity to apply ethical theories instead of embarking upon, and experimenting with, a contemplative exercise of theorizing the ethical and the unethical.

We have chosen to examine the process of theorizing as a pedagogic approach using business ethics as an example of what happens when it is considered solely as an auxiliary component in a Business Schools' curricula, as set of (best practice) prescriptions. Offered to students as theory-free (and, for that matter, value-free) thus revenant to the real world, they exclude critical reflection, practical philosophical considerations, and historical and contextual deliberations. Our aim is to highlight the importance for academics and students to be co-responsible for theorizing and to suggest that this offers the potential to co-create Business Schools as new and distinctive academic spaces of the dialogical knowledge creation (Freire, 2010 [1968]).

We envisage an exciting opportunity here. Business Schools of the future could be transformed into places increasingly open to the introduction of critical pedagogies, in which the dominant yet failing epistemologies in management education are questioned more deeply. This critical and immensely practical approach to learning, informed by moral philosophy, will inevitably include increased attention to issues currently neglected in the curriculum, such as cultural sensitivity, language, embodiment, values, vulnerabilities, ideological struggle, (in)equality and collaborative meaning making in the context of the contemporary socio-economic world order.

We do not underestimate the challenge of achieving such a transformation. The economic and political context is resistant. An obsessive attention to career 
pathways and employability increasingly define the Business School curriculum in ways that mitigate against the freedom required to theorize (see Clegg and RossSmith, 2003 and Cicmil and Hodgson, 2007, among others).

The chapter unfolds as follows. First we address the risk of emphasizing "the applied" by using business ethics as an example of what happens when it is considered solely as an auxiliary component in a Business Schools' curriculum. We illustrate our point with anonymized examples of three Business Schools' alumni accused of unethical practice. We then imagine a hypothetical classroom in a Business School that seeks to "theorize" rather than to "apply" knowledge. This is followed by a brief explanation of how we are using the concept of theorizing and its importance for academic practice and the construction of our being in the world. We continue by critically discussing how Business Schools have moved away from theorizing by centring the academic life, in particular teaching, around the applicability of theories rather than their creation, illustrated by a typical approach to the design of assessments. We finish the chapter by imagining Business Schools of the future as spaces of theorizing and how this represents an opportunity for Business Schools to transform themselves in unique and distinctive places of good learning practices.

\section{Real-world business ethics - the nature of relevant knowledge}

Traditional approaches to business ethics in Business Schools have typically considered ethics as an addition to business practices and not as a constitutive element of scientific research and theoretical reflection. In this way it has become merely a "component" that should be taken into account when reflecting or teaching business almost always based on the application of models and theories of ethics (see for example Crane and Matten, 2010; Bowie, 1999 and Jones et al, 2005). 
Considering ethics solely as an auxiliary component of business practice in this way is challenged by approaches in other social sciences. For example, the "ethic of fieldworking" is intrinsically embedded in the anthropological practice. There is no way of keeping separate the ethnographic practice from its ethical dimension. When defining the relation between research and ethics, values and ethics are "not simply supplemental to the practice of science but are an integral part of it...values are integral to the nature of knowing and being" (Barad, 2007, 37, quoted in Ezzamel and Willmott, 2014).

Our call for greater attention to the practice of theorizing in Business Schools is reflected in Liedman's (2013) argument that the ethical should be a constitutive part of our practices of theorizing and researching in business and management. Liedman suggests that the Nichomachean Ethics is not an abstract discussion on ethics but on "praxis". Without developing a capacity for theorizing it is not possible to practice genuine reflection on business situations that might constitute unethical practice , where the awareness and validation of values, morality and public versus private ethics deliberations are critical (Flyvbjerg, 2001; Curry, 2011).

What the bad business guys do: Criminals in the classroom

The following short case illustrations we have fictionalized are based on true stories:

Tom X, MBA from a prestigious Business School, became famous for his role in the development of the market for high-yield bonds (also called junk bonds) during the 1970s and 1980s, and pleaded guilty to multiple federal charges of violation US securities laws. At the same time he was a cofounder of the Tom X Foundation, chairman of the Tom's Institute, and founder of medical philanthropies funding research into melanoma, cancer and other life-threatening diseases. 
John $Y, M B A$ from top ranked ABC School of Business, chairman and CEO during the scandalous bankruptcy of one of the most important investment banks of Wall Street (2008), set up the John and Julian Family Foundation.

Pedro Y, MBA from one of the top ranked European Business School, is under investigation for fraud in connection with a major corruption scandal that involves him in the management of several charities, including one for disabled children, allegedly used to channel funds from public contracts to private offshore bank accounts belonging to him.

For our purposes, one of the most important features of these case illustrations is that not one of the three alumni has been invited by their Business Schools to return to explain what happened to them. It is possible that they would not accept the invitation, but it says something about the approach to teaching that only those who are considered successful tend to be included as exemplars. Are Business School places where the unethical behaviour of their alumni could not be discussed? What are the implications for this in the learning process?

Indeed, Business Schools are increasingly seen as places which have difficulty in initiating discussions of ethics from theoretical and critical perspectives (Page and Gaggiotti, 2012). These difficulties might be related to the rapid expansion of Business Schools (Hopfl, 2005). Their popularity in attracting large numbers of students, paying high fees, has led to them becoming an important source of income for universities (Jones and O'Doherty, 2005). Business Schools are also able to expand rapidly into profitable emerging markets through franchising, in particular with postgraduate and MBA programmes (Sturdy and Gabriel, 2000). Massproduction of graduates globally requires some standardisation to enable delivery of a contextualised knowledge across borders and by a variety of staff in the most efficient manner (thus reducing the time required for contemplation and reflection and focusing on the normative and the instrumental). Even if such expansionist and financial temptations are not the source of the problem, there is a need for 
institutions to reflect on a range of complex causes related to attitudes and personal philosophies of life (Neubaum et al, 2009) and not merely to depend upon a simple pedagogy of applying model and theories. We suggest that leaders are more likely to be unethical if they are merely been taught to apply a necessarily limited number of theories and not to be required to engage in the process of theorizing for themselves and with others.

The recent global financial crisis is an interesting case in point, with its multiplicity of debates around ethics in business. For example, considerable attention has been given to the ethical responsibilities of executives who received substantial bonuses despite their involvement in the mismanagement of their organizations. More broadly, however, a lack of ethical responsibility in major institutions has made headline news in a number of respects, such as the debate concerning the unfair distribution of wealth and the strategy of multinationals to legally avoid paying taxes.

In response to these issues alternative ways of trying to theorize business ethics have emerged. For example, a recent Economic and Social Research Council funded seminar series included an event asking, "Can ethical business leadership be encouraged through the 'disruptive innovation' of meditation?" Indeed, it could be argued that recent crises have opened up a debate around the relation between business education, self-critical reflection and ethics, all related to the need of creating a particular space and time for reflection. However, it seems that it has also emphasised the opposite: the teaching of "no time", "velocity", "speedy ('timely') decision making" as synonymous with "success", "good leadership skills", and all associated with time- and money-saving. Reference to the importance of the socalled "elevator pitch", where a student should be able to convince a hypothetical investor to be interested in her/his project in the time a lift goes from one floor to the other and to make a memorable impression. It is difficult to imagine in such a 
conversation the possibility of a profound discussion with the investor on how ethical the investment should be.

In contrast, we argue for Business Schools of the future to be transformed into what Badaracco (2002) calls places of doing the "right things", places with the time to be aware of those moments when "principles are at stake" (p. 147), "where people with strong values don't wheel and deal on matters of principle and deep conviction" ( $p$. 147), "where people do the right thing, not half of it" (p. 148).

Badaracco wonders how it might be possible to reflect appropriately on what the right thing is without the pace, tempo and time to meditate on the wrong and right and, consequently, to theorize:

Crafting responsible, workable compromises is not just something that quiet leaders do. It defines who they are... seeing things realistically, buying time, bending the rules, drilling down, looking for the best returns on political capital, nudging and testing all critical steps toward the final goal of developing workable, responsible ways to resolve everyday ethical problems. And crafting? A compromise is often the best way to do this (148-149).

Breaking the rules is an easy way out, as is following them robotically. In contrast, bending the rules is hard work. It involves exercising creativity within the boundaries set by the law, the rules, and prevailing ethical customs. It demands discipline and restraint, along with flexibility and imagination (125).

All of these practices characteristic of the practice of theorizing are marginalised as a consequence of the manner in which spaces of learning are established in Business Schools of the present.

Is it right for Business Schools just to teach future leaders that they only need to "know about" business ethics and "apply" theories instead of theorizing on the 
ethical-unethical? Ezzamel and Wilmott define this practice as "an equation that inhibits philosophical reflection upon the taken-for-granted parameters of knowledge production and so, by design or by default, exerts a deeply conservative effect on theory development" $(2014,1016)$.

Indeed, an essential distinction exists in an increasing openness toward alterity that develops in the process of ethical theorizing in contrast to the closed and totalitarian aspects of a practice of applying models (Manga, 2013). However, how can an academic space be co-created in such a way as to be more open to alterity? What would it take to experience differently the three (un-)ethical case illustrations above so that they can contribute to the theorizing of students and academics?

In the following discussion we contrast two learning scenarios: the first, a typical lecture setting; the second, a hypothetical classroom situation designed to encourage theorizing. Both are inspired by the film Wall Street II: Money Never Sleeps (Stone, 2010) and feature Gordon Gekko, a fictional business man played by Michael Douglas.

Scenario 1: Gekko is lecturing in a traditional Business School lecture theatre. Dogmatically, he explains:

Someone reminded me I once said "Greed is good". Now it seems it's legal... I was a pretty smart guy when it came to finance and maybe I was in prison too long, but sometimes it's the only place to stay sane and look out through those bars and say, 'Hey! Is everybody out there nuts?' It's clear as a bell to those who pay attention. The mother of all evil is speculation. Leveraged debt. Bottom line is borrowing to the hilt, and I hate to tell you this, but it's a bankrupt business model. Won't work. 
The students and the audience pay attention to Gekko's ideas and concepts, their applicability, his convincing rhetoric. Even if the lecturer was an experienced criminal who is exposing how relative and socially constructed business ethics is, the scenario - with him addressing the issues, exposing the problems, lecturing the audience of students and academics - defines him as the one who knows the models, the theories. The applied, practical and relevant concepts used by Gekko to explain the financial crisis are exposed diligently, pragmatically, with concrete applicability. Gekko the criminal is constructed as Gekko the lecturer, the one who knows the theories and models to apply.

Scenario 2: In our hypothetical classroom we imagine establishing a different context for Gekko, requiring different teaching and learning behaviours from him and from us, the students and academics. This context will make it difficult, if not impossible, for Gekko to address us with a univocal and instrumental lecture based on recipes and putative theories, justifying why they should be applied. Gekko would not be granted the rights of the traditional lecturer to be in a pulpit addressing a seated and immobilized audience. Both Gekko and the audience would have the same rights to ask questions, to answer, to give ideas, to propose dilemmas. Gekko would be surrounded by us, the students and academics, discussing and questioning his and our experiences of the unethical, learning the fundamentals of how to say "no" to what 'we could do and perhaps should not do' (Eco, 2014 [1980], 107). This would be achieved together by actively engaging with our questions, deconstructing how the world of Gekko works; developing, perhaps, the capacity to reconstruct Gekkothe-criminal from Gekko-the-co-learner.

Scenario 1 does not recognize any philosophical deliberations as relevant to ethical practice but Scenario 2 opens up the possibilities of learning from theorizing by contemplating Gekko-the-criminal and imagining what we could do and perhaps should not do. Indeed, theorizing is for us 'contemplation of reality', an experiential 
process of learning and the pursuit of truth through an active engagement in the world (French et al, 2015).

\section{Theorizing as contemplating our assumptions and values, our}

\section{being in the world}

It has been argued that Business Schools have focused on teaching an awareness of theory, literature, key figures, key knowledge and the crucial role that these play in the construction of the relation we establish with the world (see for example French et al, 2014, 2015). However, we believe that the practice of theorizing, in the sense of seeing the territory (contemplating, observing) has been noticeably absent in the practices that Business Schools expect from their academics and students.

The consequence of this dominant a-historical/a-temporal understanding of "applied theoretical knowledge" has been to compromise the quality and nature of a University education in this field. Further, the recognition of Business Schools as places where theorizing is absent could be precisely a way to start (re-)imagining Business Schools of the future as distinctive and original spaces of learning.

The potential consequences of this practice for the life and experience of Business School academics and students through the exclusion of students from dialogical knowledge have already been discussed (see, among others, French et al, 2015, Page and Gaggiotti, 2012). Relevant discussions have pointed out the crucial role of 
dialogical knowledge. Bakhtin considered dialogism as essential in our never ending construction of meaning:

There is neither a first nor a last word and there are no limits to the dialogic context (it extends into the boundless past and boundless future). Even past meanings, that is those born in the dialogue of past centuries, can never be stable (finalized, ended once and for all) - they will always change (be renewed) in the process of subsequent, future development of the dialogue. At any moment in the development of the dialogue there are immense, boundless masses of forgotten contextual meanings, but at certain moments of the dialogue's subsequent development along the way they are recalled and invigorated in renewed form (in a new context) (Bakhtin, 1986, 170).

Indeed, dialogical knowledge means not just presenting and extracting information, but co-creating knowledge by those who establish a dialogue. When a dialogue takes place, members of a group are encouraged to teach each other through a process of 'intellectual emancipation'. This intellectual emancipation is, in fact, a need and a right we have as humans (Rancière, 1991).

Freire stated that human nature is indeed dialogic and communication has a leading role in our life. He referred also to the dangers of exclusion when he called for a true "dialogical knowledge" in academia (Freire, 2010 [1968]). We are continuously in dialogue with others and it is in that process that we create and recreate ourselves and our understanding of the world. According to Freire, dialogue is a claim in favour of the democratic choice of educators. In order to promote free and critical learning educators should create the conditions for dialogue that encourages the epistemological curiosity of the learner. The goal of the dialogic action is always to reveal the truth by interacting with others and the world. In his dialogic action theory Freire distinguishes between dialogical actions, which promote understanding, cultural creation, and liberation; and non-dialogic actions, which deny dialogue, distort communication, and reproduce power. 
But while to say the true word-which is work, which is praxis-is to transform the world, saying that word is not the privilege of some few persons, but the right of everyone. Consequently, no one can say a true word alone-nor can she say it for another, in a prescriptive act which robs others of their words (Freire, 2010 [1968], 88).

Indeed, following Freire, the lack of dialogue, the imposition of a particular theory, the demand merely to learn to apply it and not to discuss or propose an original theory, is in fact a route to the untruth. Places where the truth is systematically obscured become not only socially unethical but also profoundly unoriginal, unimaginative, and uncritical. In such places it becomes extremely difficult for questions and responses to new dilemmas to emerge as a consequence of an imposed and repetitive way of reasoning. Is there any reason to suspect that Business Schools, with their emphasis on the "application" of theories, have become such places?

\section{An obsession with the 'applied' in Business Schools}

In our discussion so far we have addressed the risk of emphasizing "the applied" and the importance of theorizing for academic practice. In the following, we discuss how Business Schools have come to a conception of the academic life that is based upon a particular approach to the application of theory that leads to the exclusion of theorizing.

Business Schools are rooted in particular origins: the art of commerce and the industrial relation between management and work. Narratives of the origins of the early Business Schools underlined the need for increased knowledge and problem- 
solving capabilities in the practice of commerce or in the relations between workers and managers (Cruikshank, 1987; O'Connor, 1999; Khurana, 2007; Ross, 1991). In the history of the Ecole Supérieure de Commerce Paris (ESCP) the oldest Business School of the world (founded in 1891), it is stated precisely that the need for solving common "codes" of commerce was a seminal motive for the creation of the concept of business education:

ESCP Europe was founded by a group of economic scholars and businessmen including the well-known economist Jean-Baptiste Say and the celebrated trader Vital Roux. Jean-Baptiste Say was an advocate of economic liberalism and is often credited with having coined the concept of entrepreneurship as early as 1800 . Vital Roux is particularly known for having largely contributed to the elaboration of the Commercial Code in $1807 . .$. One can therefore say that the creation of ESCP Europe represents the invention of the "Business School" concept.

Although the ESCP Europe brand evolved over its almost 200 years of history, it always remained loyal to its first three letters [Ecole Supérieure de Commerce], (our emphasis). Starting in 1819 under the name Ecole Spéciale de Commerce et d'Industrie was soon after renamed Ecole Supérieure de Commerce... (ESCP, 2016)

O'Connor suggests that in the origins of Business Schools is embedded the ethos of solving managerial problems, not of theorizing. Describing the early years of Harvard Business School, she explained that many of the early large donors were CEOs seeking to find a way to resolve industrial conflict without jeopardizing their status as the central locus of organizational authority (O'Connor 1999, 120).

Indeed, the vast majority of modules taught in Business Schools advocate the application of theories and is not a requirement to learn to theorize or develop original thinking. In research practice, it is a common assumption among Business School scholars that theories should be looked for elsewhere, usually in other more theoretical disciplines, such as economics, philosophy, sociology or anthropology. 
Some Business School programmes explicitly refer to this in their pamphlets and marketing material (in the interest of anonymity the bibliographical data has been altered and is not revealed).

The module contributes to the aims and objectives of the [program's title] by building on concepts, theories and techniques introduced in first year [program's title] and Social Science courses and applying them to the evaluation and management of international business both in the short and long term (Mod. Spec. 1, 2016, 1)

Indeed, in Business Schools researchers are inclined to find ways of "using" theories rather than to develop original theories or ways of thinking. This is reflected, for example, in programme and module objectives, learning outcomes and assessment. We want to illustrate our point here by quoting from programme and module specifications we found in a range of highly ranked British Business Schools. For instance, programme objectives are usually explained to potential applicants precisely as "ways" of theoretical application, excluding any kind of invitation to develop theoretical thinking (emphasis added):

Your experience at ABC Business School (name fictitious) will help to develop your managerial style and transform you into a strategic thinker, helping to prepare you for the uncertain global environment, which we now face in business. When you leave ABC Business School you will feel confident in applying and using theory in a practical way, after trialing your concepts on the MBA during the Consultancy Project (Prog. Spec. 1, 2016, 1)

The XYZ MBA is designed to help you transform into a world-class business leader. By choosing to study an MBA at XYZ you will have the opportunity to develop your strategic, analytical and critical thinking by applying theoretical concepts to global business situations, as well as enhance your capabilities for leading and managing people (Prog. Spec. 2, 2016, 2) 
Module objectives are also defined as an opportunity for students to engage in the practical application of theories, not to theorize (emphasis added):

This module aims to introduce you to the theoretical background for the application of portfolio selection and asset pricing and accustom them with applying modern portfolio theory for the practice of investment management (Mod. Spec. 2, 2016, 1)

To introduce key theories of globalization, ethics, international trade, foreign direct investment, regional economic integration, international finance, and to apply these theories to analyse international business cases (Mod. Spec. 3, 2016, 1)

Learning outcomes are also defined in terms of applicability. Successful learning will indeed happen if students demonstrate their capacity to apply theories. Original thinking, abstract reflection, creative modeling or imaginative solutions are not considered learning outcomes (emphasis added):

Apply the theories to analyse situations and cases in international business and forward arguments to justify or critique aspects of global business activity and regulation (Mod. Spec. 3, 2016, 2)

To enable students to apply economic theory in a variety of business situations (Prog. Spec. 3, 2016, 3)

Possess the ability to apply and transfer theoretical underpinning \& contemporary management techniques within complex global organisational context (Prog. Spec. 4, 2016, 1)

Be capable of applying practical skills and techniques of undertaking management research and applying theoretical knowledge to strategic issues in a real business context (Prog. Spec. 4, 2016, 1) 
Apply theories and concepts of organisation analysis, leadership and change that reflects a sensitivity to issues relating to ethics, CSR, sustainability and governance [A and B] (Mod. Spec. 4, 2016, 2)

Assessment is also explicitly designed to focus student attention upon application.

Students are rewarded when they demonstrate the capacity to "apply" theories, to make links between "theory" and "practice" or to "use" theories, as if concepts or theories were "tools" with concrete functions (emphasis added):

You would need to demonstrate your ability to analyze and apply financial theory (Mod. Spec. 6, 2016, 2)

Apply ideas from the class (lectures, readings) to analyze the case situation. You should make use of concepts and theories from previous sessions. For example, Case Two in Session 5 can focus on relevant material presented in Sessions 1, 2, 3, and/or 4. (20\%) (Mod. Spec. 6, 2016, 1)

Demonstrating that you have understood and are able to apply theory to current change situations is essential for successful completion of the module assessment. It is also a valuable preparation for the workplace (Mod. Spec. 4, 2016, 1)

Apply theories and concepts in devising appropriate marketing strategies and policies within a changing context to meet the needs of stakeholders (Components A and B) (Mod. Spec. 5, 2016, 2)

As a consequence, the approach to theoretical thinking in Business Schools is different. The dominant premise is that theories should be reviewed, scrutinized, and explored, in order to evaluate their applicability. 


\section{Business Schools as unique places of learning}

The following question remains: into what kind of spaces should Business Schools of the future be transformed to facilitate theorizing?

Drawing on pedagogic practices in teaching business ethics at Business Schools, we have questioned the lack of theorizing as well as its marginalization in the contemporary Business School educational space. By contrast, we are advocating the development of an environment that is conducive to a more rigorous engagement with the experience of theorizing. It is in this sense that we imagine university Business Schools of the future as arenas of dialogue, discussion, and debate encouraging and requiring students to engage in co-enquiry, critical thinking and theorizing. Such an academic space will require a rigorous engagement with experience as the pursuit of truth (Freire, 2010 [1968]).

We claim that theorizing could help academics and students to cope with the anxiety and sometimes helplessness inherent in the contemporary educational experience by giving the conditions for a kind of existential hermeneutic reflection on what business and management knowing and learning might be about. It might even provide an environment conducive to a caring and careful contemplation of their own 'being in the world' (Tomkins and Simpson, 2015).

We also claim that this is an opportunity for Business Schools to redefine themselves as places offering the opportunity to engage in deep theorizing. We imagine that such programmes would become distinctive, building reputations for creativity and innovation. For example, the new curriculum for a programme could be established by working at a high level of complexity with only one socioeconomic, organizational or business critical event from a multitude of perspectives. This would 
contrast strongly with the current multiplicity of disciplines, each of them with dispersed learning agendas, methods of assessment and modules fragmented into simple, 'bite-sized' elements. In such a context, a critical event (a concrete business ethical dilemma, for example) could be defined maieutically by students and academics working together.

The programme would be designed to allow for the time needed to contemplate, reflect, theorize and propose solutions. The purpose of assessment would be not merely to evaluate the rhetorical arguments of students demonstrating theoretical applicability but to unleash the capacity of both students and academics for the creation of multiple original concepts to explain the event and to learn from the enthusiasm, frustration and anxieties they experience on the programme. A place like this would be distinctive, producing resilient thinkers with the capacity to work together, intensively scrutinizing the details of a business dilemma and suggesting new ways of knowing through contemplation and reflection.

Physically, the spaces would be different. For example, the architecture of static classrooms will be reconceived to acknowledge the reality that walking influences our thinking, opens up the free flow of ideas, and improves divergent creativity (Oppezzo and Schwartz, 2014). Currently, it is the right of tutors and teachers to circulate around the classes and the obligation of students to remain seated. Business Schools of the future as places of theorizing will allow both to move in and out of the buildings; the movement equally permitting immersion in own individual thinking as well as engaging all the participants in the learning process in dialoguing with a polyphony of voices. In this sense, perhaps we can imagine Business Schools transiting "back to the future" and becoming similar to Plato's Academy. 


\section{References}

Badaracco, J. (2002). Leading quietly. Un Unorthodox guide of doing the right thing. Boston: Harvard Business School Press.

Bakhtin, M. (1986). Speech Genres and Other Late Essays. Edited by Caryl Emerson and Michael Holquist. Translated by Vern W. McGee. Austin, TX: University of Texas Press.

Barad, K. (2007). Meeting the universe halfway: Quantum physics and the entanglement of matter and meaning. Durham, NC: Duke University Press.

Boni, A. and Walker M. (eds.) (2013). Human Development and Capabilities: Reimagining the university of the twenty-first century London: Routledge.

Bowie, N. E. (1999). Business Ethics: A Kantian Perspective. Oxford: Blackwell Publishers.

Cicmil, S. and Hodgson, D. (2007). Risks of innovation in management education: Introducing a critical management perspective onto a project management MBA elective. In: IRNOP XII Conference (International Research Network on Projects): Projects in Innovation, Innovation in Projects. Brighton, UK. 
Clegg, S. and Ross-Smith, A. (2003). Revising the boundaries: Management education and learning in postpositivist world, Academy of Management Learning and Education, 2(1), 85-98.

Crane, A. and Matten, D. (2010). Business Ethics: Managing corporate citizenship and sustainability in the age of globalization. Oxford: Oxford University Press.

Cruikshank, J. L. (1987). A delicate experiment: The Harvard Business School. 19081945. Boston: Harvard Business School Press.

Curry, P. (2011). Ecological Ethics. Cambridge: Polity Press.

Czarniawska, B. (2013). 'What Social Science Theory is and what it is not', in Corvellec, H. (ed.) What is theory? Answers from the Social and Cultural Sciences. Copenhagen: Liber CBS Press, 99-118.

Eco, U. (2014) [1980]. The Name of the Rose. Boston-New York: Mariner Books.

ESCP (2016). ESCP Europe, The World's First Business School.

http://www.escpeurope.eu/escp-europe/history-of-escp-europe-business-school/ accessed February 2016.

Ezzamel, M. and Wilmott, H. (2014). Registering 'the Ethical' in Organization Theory Formation: Towards the Discourse of an 'Invisible Force', Organization Studies, 35(7), 1013-1039. 
Flyvbjerg, B. (2001). Making Social Science Matter: Why social inquiry fails and how it can succeed again. Cambridge: Cambridge University Press.

Freire, P. (2010) [1968]. The Pedagogy of the Oppressed. New York/London: Continuum.

French, R., Gaggiotti, H. and Simpson, P. (2014). Journeying and the experiential gaze in research: Theorizing as a form of knowing, Culture and Organization. 20(3), 185195.

French, R., Gaggiotti, H. and Simpson, P. (2015). "Should We Teach Students to Theorize? Classical Greek Philosophy and the Learning Journey", in Mabey et al. Questions Business Schools don't ask. London: Sage.

Hopfl, H. (2005). 'Indifference', in Manifestos for the Business School of Tomorrow, Jones, C. and O'Doherty, D. (eds.) Dvalin Books.

Jones, C and O'Doherty, D. (eds.) (2005). Manifestos for the Business School of Tomorrow, Dvalin Books.

Jones, C., Parker, M. and Ten Bos, R. (2005). For business ethics. London: Routledge.

Khurana, R. (2007). From Higher Aims To Hired Hands. The Social Transformation of American Business Schools and the Unfulfilled Promise of Management as a Profession. Princeton: Princeton University Press. 
Liedman, S-E. (2013). 'Beholding, explaining, and predicting - The history of the concept of theory', in Corvellec, H. (ed.) What is theory? Answers from the Social and Cultural Sciences. Copenhagen: Liber CBS Press, 25-42.

Manga, E. (2013). 'History of ideas at the end of Western dominance, in Corvellec, H. (ed.) What is theory? Answers from the Social and Cultural Sciences. Copenhagen: Liber CBS Press, 48-63.

Macfarlane, B. (1998). Business Lecturers in Higher Education: Outsider Reputations, Insider Values. Paper presented at Higher Education Close Up, an international conference. University of Central Lancashire, Preston. 6-8 July 1998. Retrived from http://www.leeds.ac.uk/educol/documents/000000678.htm (Accessed 28/6/2016).

Mod. Spec. 1 (2016). Module Specification. International Management. XDF Business School.

Mod. Spec. 2 (2016). Module specification. Theory and Business. DSD Business School.

Mod. Spec. 3 (2016). Module Specification. International Management. DSD Business School.

Mod. Spec. 4 (2016). Module Specification. Leadership and Change Management. RES Faculty of Business and Law.

Mod. Spec. 5 (2016). Module Specification. Marketing. FTR Business School. 
Mod. Spec. 6 (2016). Module Specification. Finance. FTR Business School.

Neubahm, D., Pagell, M., Drexler Jr, J., McKee-Ryan, F., and Larson, E. (2009).

Business education and its relationship to student moral philosophies and attitudes towards profits: An empirical response to critics, Academy of Management Learning and Education 8(1), 9-24.

O'Connor, E. (1999). The politics of management thought: a case study of the Harvard Business School and the Human Relations School, Academy of Management Review 24(1), 117-131.

Oppezzo, M and Schwartz, D. (2014). Give Your Ideas Some Legs: The Positive Effect of Walking on Creative Thinking, Journal of Experimental Psychology: Learning, Memory, and Cognition 40(4), 1142-1152.

Page, M. and Gaggiotti, H. (2012). A visual inquiry into ethics and change, Qualitative Research in Organizations and Management: An International Journal 7(1), $72-85$.

Prog. Spec. 1 (2016). MBA Programme Specification. XYZ Business School.

Prog. Spec. 2 (2016). MBA Programme Specification. ABC Business School.

Prog. Spec. 3 (2016). Programme Specification BA (Hons) Economics. DFV School of Business.

Prog. Spec. 4 (2016). Programme Specification MBA. DFV University. 
Rancière, J. (1991). The ignorant schoolmaster. Five lessons in intellectual emancipation. Stanford: Stanford University Press.

Ross, D. (1991). The origins of American social science. Cambridge: Cambridge University Press.

Stone, O. (Producer \& Director) (2010). Wall Street II: Money Never Sleeps. USA: 20th Century Fox.

Sturdy, A. and Gabriel, Y. (2000). Missionaries, mercenaries or car salesmen? MBA teaching in Malaysia, Journal of Management Studies 37(7), 979-1001.

Tomkins, L. and Simpson, P. (2015). Caring Leadership: A Heideggerian Perspective, Organization Studies 36(8), 1013-1031. 